\title{
Implementasi Pembelajaran Biologi dengan Metode EPA untuk Meningkatkan Keterampilan Proses Sains dan Hasil Belajar Kognitif Siswa
}

\author{
Taufik Samsuri \\ Prodi Pendidikan Biologi, FSTT, Universitas Pendidikan Mandalika, J1. Pemuda No. \\ 59A, Mataram, Indonesia 83125 \\ Email Korespondensi: taufiksamsuri@undikma.ac.id
}

\section{Sejarah Artikel}

Dikirim: April 2021

Diterima: May 2021

Dipublikasi: June 2021

\section{Kata Kunci}

Eksplorasi Pengenalan; Aplikasi konsep;

Keterampilan Proses

Sains; Hasil Belajar

Kognitif

\begin{abstract}
Abstrak
Penelitian ini bertujuan untuk meningkatkan keterampilan proses sains dan hasil belajar kognitif siswa kelas VIIB SMP Negeri 3 Mataram. Jenis penelitian ini adalah penelitian tindakan kelas (PTK) yang dilakukan dalam dua siklus. Masing-masing siklus terdiri dari tahap perencanaan, pelaksanaan tindakan, pengamatan, serta refleksi, pendekatan yang digunakan adalah pendekatan kuantitatif dan pendekatan kualitatif. Subjek penelitian adalah siswa kelas VIIB SMP Negeri 3 Mataram dengan jumlah 29 orang. Instrumen penelitian berupa lembar obsevasi yang digunakan untuk mengukur keterlaksanaan keterampilan proses sains dan kegiatan guru, tes hasil belajar tipe soal pilihan ganda berjumlah 20 soal. Hasil penelitian menyatakan bahwa (1) keterlaksanaan kegiatan pembelajaran guru siklus I 75\% dengan kategori baik meningkat menjadi sangat baik di siklus II dengan persentase $83 \%$. (2) peningkatan keterampilan proses sains siswa dari siklus I 50\% dengan kategori cukup terampil meningkat menjadi $77 \%$ dengan kategori terampil pada siklus II. (3) peningkatan ketuntasan hasil belajar kognitif siswa dari siklus I 61,03\% ke siklus II 70,52\%, dengan selisih peningkatan sebesar 9,49\%, maka dapat disimpulkan bahwa melalui metode pembelajaran EPA (Eksplorasi Pengenalan dan Aplikasi konsep) dapat meningkatkan keterampilan proses sains dan hasil belajar kognitif siswa kelas VIIB SMP Negeri 3 Mataram.
\end{abstract}

\section{Implementation of Biology Learning with the EPA Method to Improve Students' Science Process Skills and Cognitive Learning Outcomes}

\section{Article History}

Received: April 2021

Accepted: May 2021

Published: June 2021

Key Words

Introductory Exploration; Concept application; Science Process Skills; Cognitive Learning Outcomes

\begin{abstract}
This study aims to improve science process skills and cognitive learning outcomes of class VIIB students of SMP Negeri 3 Mataram. This type of research is classroom action research (CAR) which is carried out in two cycles. Each cycle consists of stages of planning, implementing actions, observing, and reflecting, the approach used is a quantitative approach and a qualitative approach. The research subjects were students of class VIIB SMP Negeri 3 Mataram with a total of 29 people. The research instrument was in the form of an observation sheet used to measure the implementation of science process skills and teacher activities, a test of learning outcomes of the multiple choice type with 20 questions. The results of the study stated that (1) the implementation of teacher learning activities in cycle I was 75\% with a good category increasing to very good in cycle II with a percentage of $83 \%$. (2) the improvement of students' science process skills from 50\% in the first cycle with the moderately skilled category increased to $77 \%$ with the skilled category in the second cycle. (3) the improvement of students' cognitive learning completeness from cycle I $61.03 \%$ to cycle II $70.52 \%$, with a difference of increase of $9.49 \%$, it can be concluded that through the EPA learning method (Exploration Introduction and Concept Application) can improve science process skills and cognitive learning outcomes of class VIIB students of SMP Negeri 3 Mataram.
\end{abstract}


Samsuri, T. (2021). Implementasi Pembelajaran Biologi dengan Metode EPA untuk Meningkatkan Keterampilan Proses Sains dan Hasil Belajar Kognitif Siswa. Lensa: Jurnal Kependidikan Fisika, 9(1), 101-112. doi:https://doi.org/10.33394/j-1kf.v9i1.4356

\section{PENDAHULUAN}

Jhon Dewey mendefinisikan pendidikan adalah proses pembentukan kecakapan fundamental secara intelektual dan emosional kearah alam dan manusia, dengan kata lain sebagai usaha pengembangan pontensi individu peserta didik. Kleis berpendapat bahwa pendidikan adalah sejumlah pengalaman dengan pengalaman itu, seseorang atau kelompok orang dapat memahami sesuatu yang sebelumnya tidak mereka pahami, pengalaman terjadi karena adanya interaksi antara seseorang atau kelompok dengan lingkungannya, interaksi itu menimbulkan proses perubahan (belajar) pada manusia, dan selanjutnya proses perubahan itu menghasilkan perkembangan (Development) bagi seseorang atau kelompok di dalam lingkungannya (Rohman, 2012).

Undang-Undang No. 20 Tahun 2003 tentang Sistem Pendidikan Nasional, Pasal 1 ayat 1 disebutkan bahwa pendidikan adalah usaha dasar dan terencana untuk mewujudkan suasana belajar dan proses pembelajaran agar peserta didik secara aktif mengembangkan potensi dirinya untuk memiliki kekuatan spiritual keagamaan, pengendalian diri, kepribadian, kecerdasan, akhlak mulia, serta keterampilan yang diperlukan dirinya, masyarakat, bangsa dan Negara. Berdasarkan penyataan tersebut dapat dinyatakan bahwa pendidikan merupakan proses pembelajaran yang diarahkan kepada perkembangan peserta didik untuk memiliki kekuatan spiritual keagamaan, pengendalian diri, kepribadian, kecerdasan, akhlak mulia, serta keterampilan yang diperlukan dirinya, masyarakat, bangsa dan Negara (Jufri, 2013).

Berdasarkan hal tersebut dapat dikatakan bahwa pendidikan merupakan aspek yang sangat penting, karena pendidikan mempengaruhi, membantu, dan mengarahkan manusia dalam mencapai kedewasaan sesuai dengan kualifikasi yang ditetapkan masyarakat, untuk mencapai tujuan pendidikan, maka diperlukan adanya proses pembelajaran yang optimal, efektif dan berkualitas, bagi siswa agar terjadi proses belajar mengajar yang efektif untuk mencapai hasil yang sesuai dengan tujuan (Misnah, 2014).

Keterampilan proses sains (KPS) sangat penting dimiliki siswa untuk menghadapi persaingan di era globalisasi yang menuntut adanya persaingan antarmanusia. Berkaitan dengan hal tersebut, Haryono (dalam Budiyono., dkk, 2016) mengungkapkan bahwa KPS sangat penting dikembangkan dalam pendidikan karena merupakan kompetensi dasar untuk mengembangkan sikap ilmiah dan keterampilan dalam memecahkan masalah, sehingga dapat membentuk pribadi siswa yang kreatif, kritis, inovatif, dan kompetitif dalam persaingan global di masyarakat.

Selain itu, alasan yang melandasi perlunya keterampilan proses sains dalam kegiatan belajar mengajar dikemukakan oleh Samsuri (2016), KPS perlu dikembangkan karena dengan keterampilan proses seseorang akan mampu belajar mandiri, mengembangkan diri sendiri, dan belajar sepanjang hayat. Keterampilan proses sains merupakan keterampilan yang diperlukan dalam melakukan penelitian dan memecahkan masalah. Kemampuan pemecahan masalah ini merupakan salah satu kecakapan hidup (Life skills) yang perlu dimiliki siswa sebagai bekal dalam meneruskan kehidupannya. Mengatasi hal-hal ini perlu pengembangan keterampilan memperoleh dan memproses semua fakta, konsep, dan prinsip pada diri siswa agar anak dapat berlatih untuk selalu bertanya, berfikir kritis, menumbuh-kembangkan keterampilan fisik dan mental serta sebagai wahana untuk menyatukan pengembangan konsep dengan pengembangan sikap dan nilai yang penting sebagai bekal terhadap tantangan di era globalisasi. 
Meskipun demikian, kenyataan yang terjadi di dunia pendidikan, keterampilan proses sains belum dikembangkan secara optimal. Nandang (dalam Budiyono, 2016), mengungkapkan bahwa proses penyelenggaraan pendidikan di sekolah belum megoptimalkan berbagai keterampilan yang dimiliki siswa, hal ini salah satunya disebabkan oleh pembelajaran yang bersifat umum dan teoritik serta kurang menuntut siswa menggunakan alat pikirnya, sementara dalam masyarakat siswa dituntut untuk mampu menggunakan keterampilan secara optimal.

Pernyataan di atas juga didukung fakta yang terjadi di lapangan. Hasil observasi dan wawancara peneliti dengan guru biologi SMPN 3 Mataram, menunjukkan bahwa KPS siswa kelas VIIB di sekolah tersebut masih kurang misalnya merencanakan percobaan, menerapkan konsep dan lain sebagainya, selain itu metode yang sering digunakan guru dalam pembelajaran biologi khususnya pada materi pencemaran lingkungan adalah metode bersifat umum dan teoritik. Metode-metode tersebut diduga kurang mampu memfasilitasi siswa untuk mengembangkan keterampilan proses sains (KPS).

Hasil observasi juga menunjukkan bahwa pengembangan KPS baik dalam proses pembelajaran maupun evaluasi hasil belajar sangat jarang dilakukan, sehingga siswa kurang mampu mengembangkan keterampilan dalam menemukan dan menghubungkan konsep yang disampaikan khususnya pada materi pencemaran lingkungan. Mengingat pentingnya keterampilan tersebut, maka diperlukan metode pembelajaran yang dapat memfasilitasi terselenggaranya kegiatan pembelajaran yang mampu mengembangkan KPS siswa. Salah satu metode pembelajaran yang diharapkan dapat mengembangkan KPS siswa adalah pembelajaran dengan menggunakan metode EPA (Eksplorasi Pengenalan dan Aplikasi Konsep). Berdasarkan pernyataan-pernyataan tersebut menjadi salah satu pemicu rendahnya hasil belajar biologi siswa. Berikut Tabel 1 hasil belajar peserta didik.

Tabel 1. Perolehan Nilai UTS Semester 1 Siswa Kelas VII SMPN 3 Mataram

\begin{tabular}{clcl}
\multirow{2}{*}{ Kelas } & \multirow{2}{*}{ Jumlah siswa } & \multicolumn{2}{l}{ KKM $\geq 75$} \\
\cline { 2 - 4 } & & Tuntas & Tidak Tuntas \\
\hline VII A & 29 & 14 & 15 \\
\hline VII B & 29 & 10 & 19 \\
\hline
\end{tabular}

Sumber : Daftar Guru Nilai IPA Biologi SMPN 3 Mataram

Tabel 1 menunjukkan bahwa hasil belajar siswa kelas VIIA pada mata pelajaran IPA di SMPN 3 Mataram terbilang masih tinggi dari kelas VIIB, siswa dikatakan tuntas belajar secara individual bila mencapai nilai ketuntasan $\geq 75$ sesuai KKM yang ada di SMPN 3 Mataram Tahun Pelajaran 2017/2018 dan suatu kelas tuntas bila kelas tersebut mencapai ketuntasan klasikal $\geq 85 \%$, siswa dikatakan belum tuntas secara individual karena nilai rata-ratanya belum mencapai ketuntasan $\geq 75$.

Berdasarkan uraian kajian empiris dan hasil obeservasi awal, penelitian ini bertujuan untuk mengimplementasi pembelajaran biologi dengan Metode EPA (Eksplorasi Pengenalan dan Aplikasi Konsep) untuk meningkatkan keterampilan proses sains dan hasil belajar kognitif siswa di kelas VIIB SMP Negeri 3 Mataram.

\section{METODE}

Jenis penelitian yang digunakan adalah Penelitian Tindakan Kelas (PTK). Penelitian tindakan kelas adalah suatu perencanaan terhadap kegiatan belajar yang dilakukan oleh guru berupa sebuah tindakan yang sengaja dimunculkan dan terjadi dalam sebuah kelas secara bersama dengan tujuan untuk memperbaiki kinerjanya sebagai guru, sehingga hasil belajar siswa dapat meningkat (Arikunto, 2006). 
Pendekatan yang digunakan dalam penelitian ini adalah pendekatan kuantitatif dan kualitatif, dimana pendekatan kualitatif adalah data yang diperoleh dalam bentuk kalimat, gambar atau kata. Sedangkan pendekatan kuantitatif yaitu data yang diperoleh peneliti dalam bentuk angka, atau data kualitatif yang diangka kan (skoring) (Sugiyono, 2014).

Adapun rancangan penelitian yang digunakan adalah Penelitian Tindakan Kelas (PTK) dimana pelaksanaan penelitian ini direncanakan dalam 2 siklus, setiap siklus dalam penelitian tindakan kelas terdiri dari empat tahapan, yaitu : perencanaan, pelaksanaan, pengamatan dan refleksi, adapun model dan penjelasan untuk masing - masing tahap dapat dilihat pada Gambar 1. Penelitian ini dilaksanakan pada bulan Maret 2018 semester genap kelas VIIB SMP Negeri 3 Mataram.

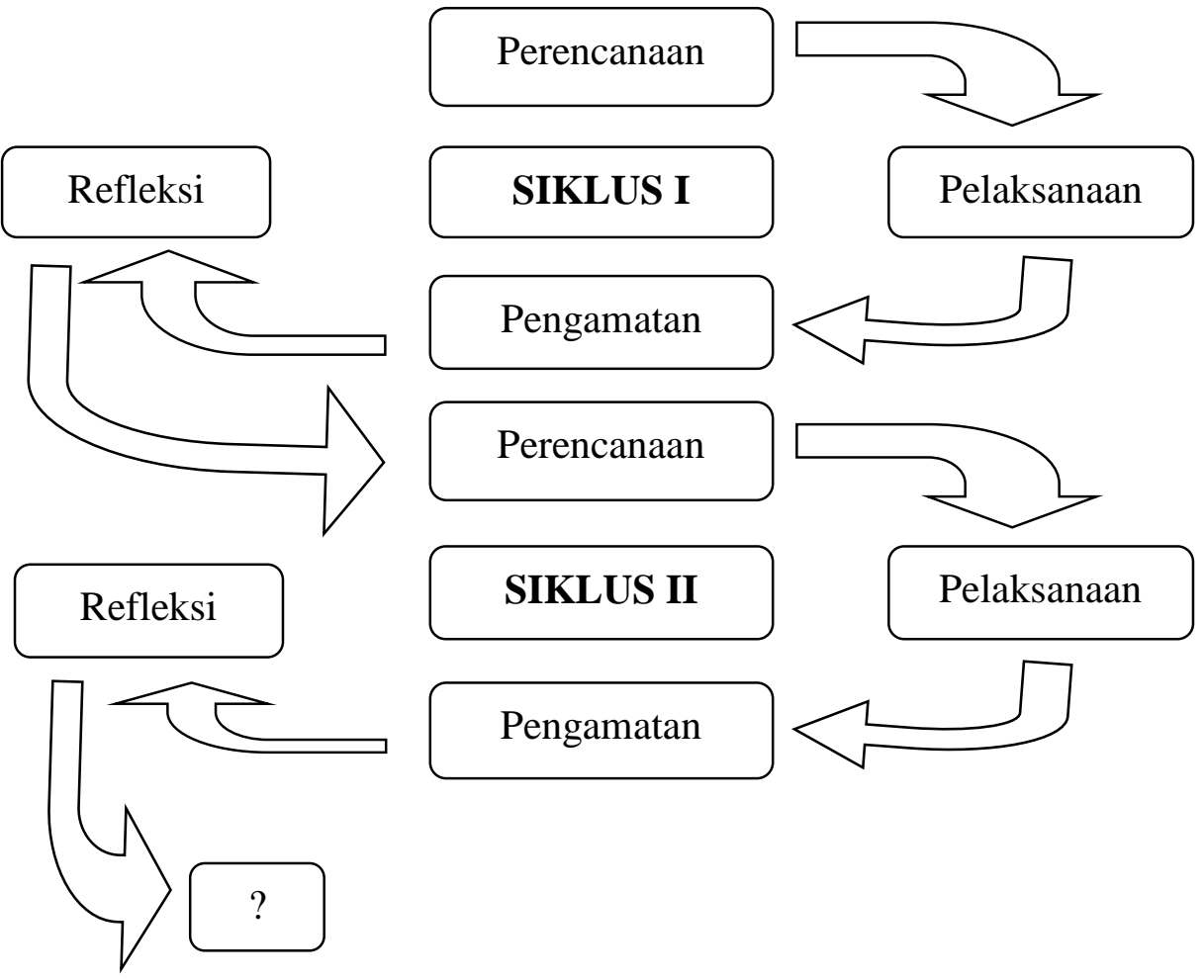

Gambar 1. Model Penelitian Tindakan Kelas (Arikunto, 2006)

\section{Instrumen Penelitian} berikut.

Adapun instrumen penelitian yang digunakan dalam penelitian ini adalah sebagai

\section{Lembar Observasi}

Lembar observasi adalah alat yang digunakan untuk mengukur keterlaksanaan proses pembelajaran siswa pada saat proses pembelajaran untuk memperoleh data mengenai keterampilan proses sains dan keterlaksanaan kegiatan guru dan siswa.

\section{Lembar Tes}

Merupakan serangkaian pertanyaan atau latihan yang digunakan untuk memperoleh hasil belajar setiap siklus, adapun bentuk soal tes yaitu pilihan ganda sebanyak 20 soal untuk masing-masing siklus. Soal yang digunakan diambil dari buku paket biologi SMP, sehingga soal tersebut diasumsikan sudah valid dan realiabel dengan demikian peneliti tidak perlu mengkaji validitas dan reliabilitas tes. 


\section{Teknik Pengumpulan Data}

Adapun sumber data pada penelitian ini adalah dari peneliti, observer, dan siswa kelas VIIB semester II SMP Negeri 3 Mataram, dan cara pengambilan data dalam penelitian ini adalah teknik tes berupa pilihan ganda untuk memperoleh data hasil belajar dengan cara memberikan tes evaluasi yang dilakukan pada setiap akhir siklus dan teknik non tes berupa penilaian kinerja (Performance Assesment) untuk mengetahui aktivitas guru, dan keterampilan proses sains.

\section{Teknik Analisis Data}

Data hasil belajar

Setelah memperoleh data tes hasil belajar maka data tersebut dianalisis dengan mencari ketuntasan belajar, kemudian dianalisis secara kuantantif.

a. Ketuntasan individual, setiap siswa dalam belajar mengajar dikatakan tuntas apa bila siswa memperoleh nilai $\geq 75$, untuk menganalisis skor nilai yang diperoleh siswa maka digunakan rumus sebagai berikut, Subanan (dalam Amrina, 2014)

$\mathrm{KI}=\frac{X}{Z} \times 100$

Keterangan :

$\mathrm{KI}=\quad$ Ketuntasan Individual

$\mathrm{X}=\quad$ Skor Siswa

$\mathrm{Z}=\quad$ Skor Maksimal

b. Ketuntasan klasikal, data tes hasil belajar proses pembelajaran dianalisis dengan menggunakan analisis ketuntasan hasil belajar secara klasikal minimal $\geq 85 \%$ dari jumlah siswa yang memperoleh nilai $\geq 75$, dengan rumus ketentuan belajar klasikal sebagai berikut, Subanan (dalam Amrina, 2014).

$\mathrm{KK}=\frac{X}{Z} \times 100 \%$

Keterangan :

$\mathrm{KK}=\quad$ Ketuntasan klasikal

$\mathrm{X}=\quad$ Jumlah siswa yang memperoleh nilai $\geq 75$

$\mathrm{Z}=\quad$ Jumlah seluruh siswa

Ketuntasan hasil belajar siswa secara klasikal tercapai jika $\geq 85 \%$ siswa memperoleh $\geq 75$ yang akan terlihat pada hasil evaluasi pada tiap-tiap siklus.

c. Analisis nilai rata-rata hasil tes

$$
\begin{array}{ll}
\text { Nilai rata-rata }(X)=\frac{X}{Z} \\
(X)= & \text { Nilai rata-rata } \\
X= & \text { Total nilai } \\
Z= & \text { Jumlah siswa }
\end{array}
$$

2. Data keterlaksanaan pembelajaran berikut:

Keterlaksanaan pembelajaran metode EPA dianalisis melalui rumus sebagai

$\%=\frac{X}{Y} \times 100 \%$

Keterangan:

$\%=\quad$ Persentase skor

$\mathrm{X}=\quad$ Jumlah skor yang diperoleh

$\mathrm{Y}=\quad$ Jumlah skor maksimum

Tabel 2. Pedoman kategori keterlaksanaan pembelajaran (RPP) Persentase (\%) 


\begin{tabular}{cc}
\hline $80 \%-100 \%$ & Sangat baik \\
$60 \%-79 \%$ & Baik \\
$40 \%-59 \%$ & Cukup baik \\
$21 \%-49 \%$ & Kurang baik \\
$<20 \%$ & Sangat kurang baik \\
\hline
\end{tabular}

3. Data keterampilan proses sains

Teknik analisis data keterampilan proses sains pada tiap siklus mengacu pada rumus sebagai berikut:

$\mathrm{N}=\frac{S D}{S M} \times 100 \%$

Keterangan :

$\mathrm{N}=\quad$ Nilai

$\mathrm{SD}=\quad$ Skor yang didapat

$\mathrm{SM}=$ Skor maksimum

Tabel 3. Persentase Keterampilan Proses Sains Siswa

$\begin{array}{cc}\text { Persentase }(\%) & \text { Kategori } \\ 81 \%-100 \% & \text { Sangat terampil } \\ 61 \%-80 \% & \text { Terampil } \\ 41 \%-60 \% & \text { Cukup terampil } \\ 21 \%-40 \% & \text { Kurang terampil } \\ 0 \%-20 \% & \text { Sangat kurang terampil }\end{array}$

Sumber : Arikunto (dalam Misnah, 2014)

\section{HASIL DAN PEMBAHASAN}

Hasil pelaksanaan dan pengamatan penelitian pada siklus I dan siklus II berupa kegiatan guru, kegiatan siswa, keterampilan proses sains siswa, dan hasil belajar kognitif siswa menggunakan metode EPA. Penilaian kegiatan guru pembelajaran siklus I dan siklus II dapat dilihat pada Gambar 4.1 berikut:

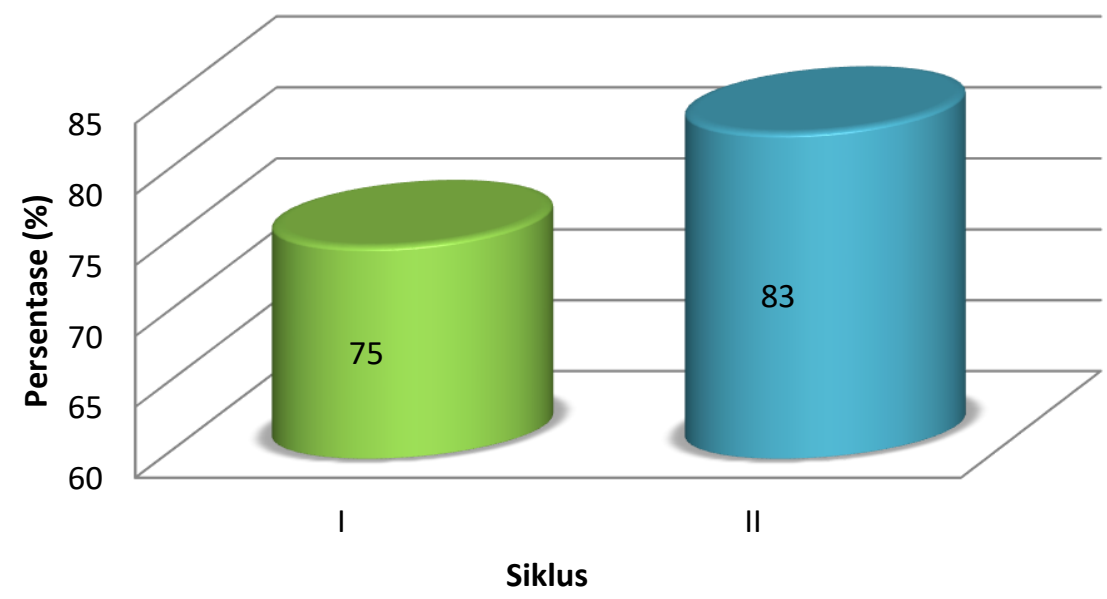

Gambar 2. Perbandingan hasil observasi kegiatan guru siklus I dan II

Hasil observasi keterlaksanaan kegiatan guru pada siklus I 75\% dengan kriteria baik, dan meningkat pada siklus II dengan perolehan nilai sebesar $83 \%$ kriteria sangat baik. Penilaian keterampilan proses sains siswa dilakukan pada saat proses pembelajaran 
berlangsung, yaitu ketika guru menggunakan metode EPA. Setiap siklus, keterampilan proses sains yang muncul berbeda - beda sesuai dengan materi pembelajaran. Adapun keterampilan proses sains siklus I dan II dapat dilihat pada Gambar 4.2:

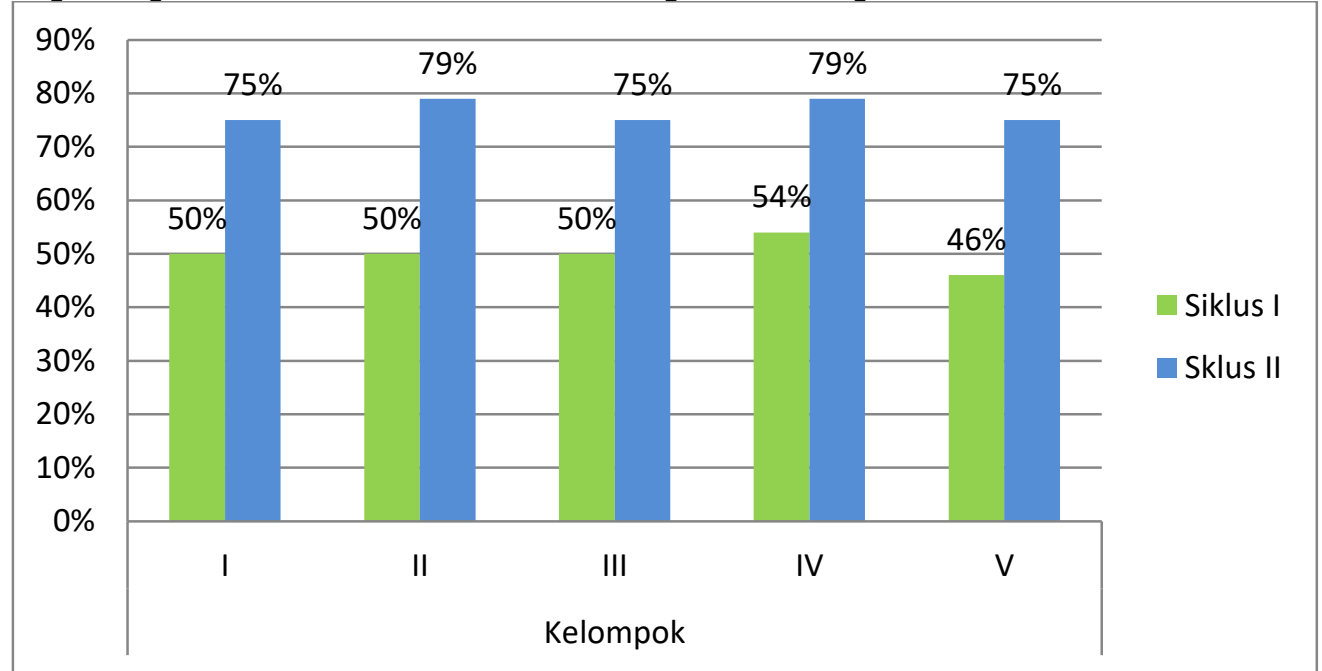

Gambar 3. Perbandingan kemampuan keterampilan proses siswa siklus I dan II

Keterampilan proses sains siswa meningkat dari siklus I ke siklus II. Total rata- rata keterampilan proses sains siswa pada siklus I sebesar 50\% dan meningkat pada sikus II dengan persentase $77 \%$. Keterampilan proses sains siswa pada siklus II meningkat $27 \%$. Peningkatan hasil belajar siswa juga merupakan salah satu tujuan dalam penelitian ini.

Perbandingan hasil belajar siswa pada siklus I dan II tersaji pada Gambar 4 berikut.

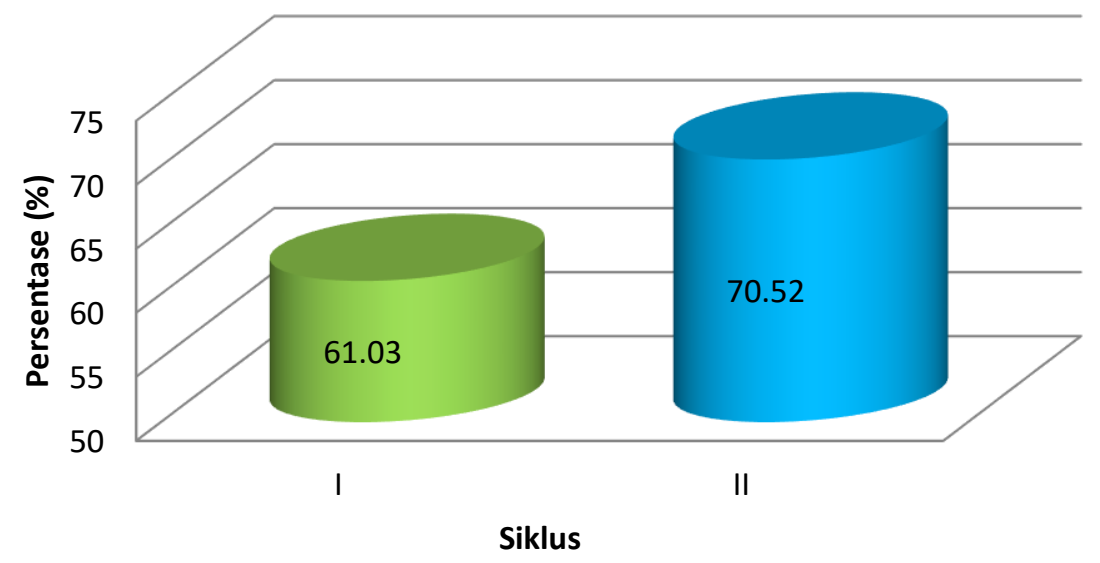

Gambar 4. Perbandingan penguasaan konsep siswa siklus I dan II

Berdasarkan hasil tes belajar siklus I dan II terlihat bahwa terjadi peningkatan hasil belajar siswa dari $61,03 \%$ pada siklus I menjadi $70,52 \%$ pada siklus II, hal ini menunjukkan bahwa terjadi peningkatan hasil belajar siswa pada materi pencemaran lingkungan dari siklus I ke siklus II sebesar 9,49\%.

Selain itu, peningkatan hasil belajar siswa juga dapat dilihat dari jumlah siswa yang tuntas menguasai konsep yang diajarkan. Pada siklus I jumlah siswa yang tuntas menguasai konsep yang diajarkan sebanyak 48,28\% meningkat menjadi $86,21 \%$ pada siklus II, hal ini dapat ditunjukkan pada Gambar 5. 


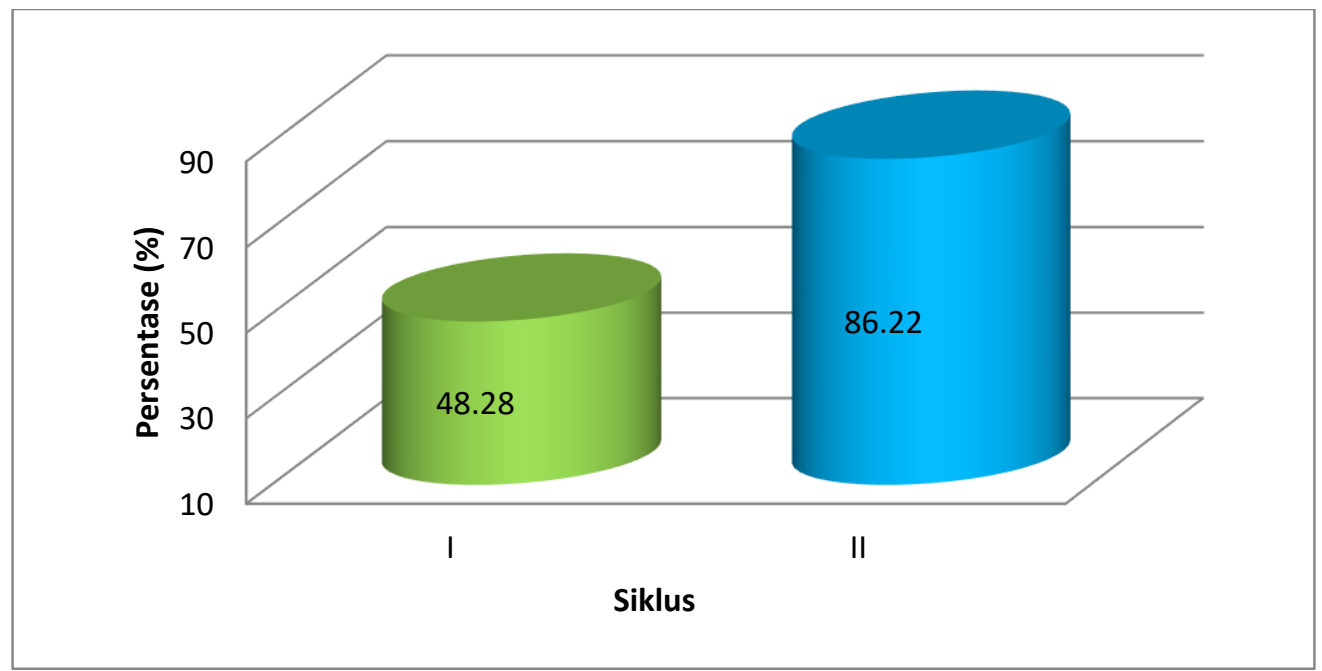

Gambar 5. Persentase kentutasan klasikal siswa pada siklus I dan II

Hasil penelitian yang diperoleh bahwa keterlaksanaan proses mengajar guru secara keseluruhan pada siklus I dan siklus II terjadi peningkatan, keterlaksanaan proses mengajar guru pada siklus I memperoleh skor sebesar $73 \%$ sedangkan pada siklus II memperoleh skor sebesar $83 \%$, dari hasil perhitungan pada siklus II menyatakan bahwa keterlaksanaan proses mengajar guru pada proses belajar mengajar menggunakan metode EPA pada siklus ini mengalami peningkatan skor yaitu sebesar 8 .

Secara umum aspek-aspek kegiatan yang terdapat pada RPP telah terlaksana dengan baik hanya beberapa aspek kegiatan yang masih belum terlaksana di awal pembelajaran (Siklus I), namun hal tersebut tidak terulang kembali pada pembelajaran selanjutnya (Siklus II) yang kegiatannya hampir semua terlaksana dengan baik dan masuk dalam kategori sangat baik. Saat pelaksanaan pembelajaran dalam kelas, ada beberapa kendala yang dihadapi peneliti yaitu pada siklus I kurangnya pengelolaan kelas dan pengelolaan waktu oleh peneliti sehingga menyebabkan suasana kelas menjadi kurang kondusif saat kegiatan pembelajaran berlangsung, hal tersebut dikarenakan peneliti masih belum terbiasa menggunakan metode EPA saat pembelajaran di kelas.

Awal pembelajaran siklus I peneliti banyak memberikan pengarahan kepada siswa untuk proses pembelajarannya, siswapun juga banyak bertanya pada saat pembelajaran seperti menanyakan langkah percobaan yang belum dipahami siswa, saat pelaksanaan percobaan, menyajikan data ke dalam tabel, menganalisis, hingga membuat kesimpulan sehingga membuat suasana kelas menjadi kurang kondusif.

Siklus II suasana kelas saat pembelajaran sudah mulai kondusif dan terkendali, siswa juga lebih sedikit bertanya dan banyak bekerja sendiri untuk melakukan percobaan sampai dengan menyelesaikan LKS percobaan masing-masing walaupun masih ada beberapa siswa yang bertanya, hal tersebut karena siswa sudah mulai terbiasa melakukan penyelidikan dalam percobaan, sudah mulai memahami sistematika percobaan, dan sudah mulai bisa menggunakan alat dengan benar. Pengamat juga berperan penting saat proses pembelajaran berlangsung, dengan bantuan pengamat pula peneliti bisa merefleksi kekurangan-kekurangan saat pembelajaran di kelas. Meningkatnya keterlaksanaan RPP pada setiap pertemuannya sesuai dengan teori yang dikemukakan oleh Supardi (dalam Ansari, 2017) yang menyatakan fungsi RPP untuk mendorong agar guru lebih siap dalam melaksanakan pembelajaran dengan perencanaan yang matang, hal tersebut menjadi dasar guru untuk selalu merefleksi hasil keterlaksanaan RPP yang dibuat oleh peneliti tersebut agar memperoleh pembelajaran yang maksimal. 
Hasil keterampilan proses sains siswa setelah melakukan penelitian dan analisa perkelompok, didapat hasil penelitian dimana keterampilan proses sains siswa meningkat dari siklus I ke siklus II, hal ini dapat dilihat pada Gambar 3. Siklus I dari kelompok I, II, III memperoleh nilai 50\% dengan kategori cukup terampil, kelompok IV memperoleh nilai $54 \%$ dengan kategori cukup terampil dan kelompok $\mathrm{V}$ memperoleh nilai $46 \%$ dengan kategori cukup terampil juga, sedangkan pada siklus II yang memperoleh katagori terampil yaitu kelompok I, III dan V dengan nilai 75\%, kelompok II dan IV memperoleh nilai $79 \%$ dengan kategori terampilan. Total rata- rata keterampilan proses sains siswa pada siklus I sebesar 50\% dan meningkat pada sikus II dengan nilai 77\%, jika dihubungkan dengan hasil pelaksanaan proses mengajar guru pada siklus I, hasil keterampilan proses sains siswa perkelompok tersebut memang sesuai dan dapat dikatakan berkesinambungan. Siklus II ini diadakan sebagai perbaikan dari siklus I untuk lebih meningkatkan keterampilan proses sains siswa. Setiap kali pertemuan siswa akan dilihat keterampilan prosesnya. Total rata-rata keterampilan proses siswa pada sikus II dengan nilai $77 \%$ dengan kategori terampil, hal ini terjadi karena siswa mendapat tindakan dari peneliti melalui metode EPA yang sudah berjalan dengan cukup efektif. Seiring meningkatnya kegiatan guru dalam pembelajaran meningkatkan keterampilan proses sains siswa, karena pada setiap tahap pembelajaran melalui metode EPA dapat melatih siswa pada keterampilan proses sains.

Meningkatnya KPS tersebut pada setiap siklusnya juga didukung oleh teori Gastalt yang menyatakan bahwa belajar merupakan proses melakukan reorganisasi pengalamanpengalaman masa lalu yang secara terus-menerus disempurnakan (Sanjaya dalam Ansari, 2017), hal senada juga diungkapkan oleh Samsuri dan Fitriani (2015) yang menyatakan bahwa Keterampilan Proses Sain (KPS) merupakan kemampuan menggunakan pikiran, nalar dan perbuatan yang didasarkan pada proses ilmiah, dengan melihat hasil refleksi pada siklus I KPS siswa direorganisasi kembali dan siswa mulai terbiasa dengan pengalaman yang dialaminya langsung untuk meningkatkan keterampilan proses sains yang diamati dengan dilakukan siswa secara terus-menerus.

Peningkatan hasil belajar siswa juga merupakan salah satu tujuan dalam penelitian ini. Berdasarkan hasil tes hasil belajar siklus I dan II terlihat bahwa terjadi peningkatan hasil belajar siswa dari $61,03 \%$ pada siklus I menjadi $70,52 \%$ pada siklus II, hal ini menunjukkan bahwa terjadi peningkatan hasil belajar siswa pada materi pencemaran lingkungan dari siklus I ke siklus II sebesar 9,49\%, dapat diketahui bahwa terjadi peningkatan ketuntasan hasil belajar siswa pada setiap siklusnya. Siklus I siswa yang memenuhi ketuntasan individu sebanyak 14 siswa dari 29 siswa yang menjadi subjek penelitian dengan ketuntasan klasikal sebesar 48,28\%, hasil tersebut belum memenuhi indikator keberhasilan penelitian yaitu ketuntasan klasikal hasil belajar siswa $\geq 85 \%$, hal tersebut dikarenakan pembelajaran dengan metode EPA masih baru bagi siswa sehingga siswa perlu beradaptasi terlebih dahulu dengan sistematika pembelajaran, hal lain yang menjadi penyebab belum mencapainya persentase ketuntasan hasil belajar siswa secara klasikal yaitu sebagian siswa belum mantap memahami soal latihan karena pada siklus I guru tidak sempat meminta siswa menuliskan hasil pekerjaan latihan siswa di papan tulis yang bisa dikoreksi bersama jika terjadi kekeliruan. Ketidaksempatan guru untuk meminta siswa menuliskan hasil belajarnya di papan tulis karena belum maksimalnya guru dalam mengelola waktu saat melaksanakan pembelajaran.

Siklus II siswa yang memenuhi ketuntasan individu sebanyak 25 siswa dari 29 siswa yang menjadi subjek penelitian dengan ketuntasan klasikal sebesar 86,21\%, hasil tersebut sudah memenuhi indikator keberhasilan penelitian yaitu ketuntasan klasikal hasil belajar siswa $\geq 85 \%$. Peningkatan hasil belajar yang dicapai siswa tidak terlepas dari kegiatan siswa saat proses pembelajaran berlangsung. Siswa telah aktif dalam kegiatan diskusi baik 
diskusi kelas maupun diskusi kelompok, bahwa melalui kegiatan belajar tim/ kelompok, siswa belajar menyampaikan pendapat berdasarkan pemahaman materi yang dibebankan sehingga konsep dapat diingat lebih lama sementara siswa dengan kelompok kemampuan rendah dapat bebas bertanya dengan teman dalam kelompok dengan kemampuan tinggi tanpa ada perasaaan malu sebab biasanya siswa akan merasa terbebani jika harus bertanya kepada guru.

Rosdiana (2013) berdasarkan hasil penelitiannya dengan menggunakan metode EPA (Eksplorasi Pengenalan dan Aplikasi konsep) dapat meningkatkan hasil belajar siswa, hal ini dapat dilihat dari perbandingan skor rata-rata siklus I dan siklus II. Hasil penelitian yang serupa juga di tunjukan oleh penelitian yang dilakukan oleh Zainifuza (2013), bahwa dengan menggunakan metode EPA (Eksplorasi Pengenalan dan Aplikasi konsep) dapat meningkatkan hasil belajar siswa.

Meningkatnya hasil belajar siswa tersebut sesuai dengan teori kontruktivis dikembangkan oleh piaget (Sanjaya dalam Ansari, 2017) pada pertengahan abad 20 yaitu pada dasarnya setiap individu sejak kecil sudah memiliki kemampuan untuk mengkontruksi pengetahuannya sendiri. Pengetahuan yang dikontruksi sendiri maka akan menjadi pengetahuan yang lebih bermakna; Piaget menyatakan bahwa pengetahuan yang terbentuk melalui proses pengalaman langsung memberikan kekuatan pada pengetahuan kognitif.

\section{KESIMPULAN}

Berdasarkan hasil penelitian terhadap siswa VIIB SMP Negeri 3 Mataram, dapat disimpulkan bahwa implementasi metode EPA dapat meningkatkan keterampilan proses sains siswa dengan perolehan nilai sebesar $50 \%$ pada siklus I dengan kategori cukup terampil, meningkat pada siklus II dengan perolehan nilai sebesar $77 \%$ dengan kategori terampil. Hasil belajar kognitif siswa secara klasikal telah mencapai indikator keberhasilan. Peningkatan ketuntasan hasil belajar siswa sebesar 9,49\%, pada siklus I sebesar $61,03 \%$ meningkat menjadi $70,52 \%$ pada siklus II.

\section{REKOMENDASI}

Adapun saran-saran yang dapat peneliti kemukakan sehubungan dengan hasil penelitian yang diperoleh adalah: Untuk penelitian selanjutnya dapat dilakukan perluasan pada aspek keterampilan proses sains serta perlu dilakukan pengembangan pembelajaran serupa pada materi biologi lainnya.

\section{UCAPAN TERIMAKASIH}

Ucapan terima kasih terutama ditujukan kepada pemberi dana pengabdian atau donatur. Ucapan terima kasih dapat juga disampaikan kepada pihak-pihak yang membantu pelaksanaan pengabdian.

\section{DAFTAR PUSTAKA}

Acesta A. 2013. Penerapan Pendekatan Keterampilan Proses Sains untuk Meningkatkan Hasil Belajar Siswa dalam Pembelajaran IPA. Jurnal Ilmiah Pendidikan Dasar.

Amelia., dkk. 2015. Meningkatkan Keterampilan Proses Sains dan Hasil Belajar Melalui Penerapan Pendekatan Scientific Materi Redoks pada Siswa Kelas X Ms 5 Sma Negeri 2 Banjarmasin. Jurnal Inovasi Pendidikan Sains, Vol.6, No.2.

Amrina. 2014. Penggunaan Model Pembelajaran Berbasis Masalah untuk Meningkatkan Sains dan Hasil Belajar Kognitif Sisa pada Mata Pelajaran Ipa di Smpn 2 Pujut Tahun Pelajaran 2013/2014. FPMIPA : Ikip Mataram. 
Ansari., dkk. 2017. Meningkatkan Keterampilan Proses Sains dan Hasil Belajar Siswa Kelas X-1 Sman 10 Banjarmasin dengan Menerapkan Model Inquiry Discovery Learning Terbimbing. Jurnal Ilmiah Pendidikan Fisika Vol 1 No. 3.

Arikunto S. 2006. Penelitian Tindakan Kelas. Jakarta: PT. Bumi Aksara.

Aryansyah, A. 2012. Penerapan Metode Pembelelajaran EPA (Eksplorasi Pengenalan dan Aplikasi Konsep) untuk Meningkatkan Aktivitas dan Hasil Belajar Siswa Kelas VIIB SMP Negeri 2 Empang Pada Materi Pokok Segitiga Tahun Pelajaran 2011/2012. FPMIPA: Ikip Mtaram.

Bahtiar. 2010. Strategi belajar mengajar sains (IPA) fisika. Modul Universitas Muhammadiyah Mataram.

Budiyono., dkk. 2016. Pengaruh Model Pembelajaran Inkuiri Terbimbing Terhadap Keterampilan Proses Sains Siswa SMA. Jurnal Pemikiran Penelitian Pendidikan dan Sains. Vol. 4, No. 2. p-ISSN : 2337-9820.

Daftar Nilai Guru IPA Biologi SMPN 3 Mataram.

Dimyati dan Mudjiono. 2015. Belajar dan Pembelajaran. Jakarta: Rineka Cipta.

Effendi R. 2016. Konsep Revisi Taksonomi Bloom dan Implementasinya pada Pelajaran Matematika SMP. Jurnal Ilmiah Pendidikan Matematika Volume 2 Nomor 1 P-ISSN: 2502-7638; E-ISSN: 2502-8391.

Fitriani, H. dan Samsuri, T. (2015). Identifikasi Keterampilan Proses Sains Mahasiswa Biologi Ditinjau dari Penyelesaian Lembar Kegiatan Mahasiswa Anatomi dan Perkembangan Tumbuhan. Jurnal Ilmiah Biologi "Bioscientist". 3(2): 395- 398.

Handayani., dkk. 2016. Peningkatan Keterampilan Proses Sains pada Pembelajaran Biologi Melalui Penerapan Model Bounded Inquiry Lab. Jurnal Bioedukasi Volume 9 Nomor 2. Issn:1693-265x.

Ibrahim M. 2010. Dasar-Dasar Proses Belajar Mengajar. Surabaya: Unesa University Press. Jufri W. 2013. Belajar dan pembelajarn sains. Bandung: Pustaka Reka Cipta.

Juhji. 2016. Peningkatan Keterampilan Proses Sains Siswa Melalui Pendekatan Inkuiri Terbimbing. Jumal Pendidikan dan Pembelajaran IPA. Vol 2 No 1. ISSN 2477-2038.

Kartimi., dkk. 2013. Penerapan Pendekatan Keterampilan Proses dalam Pengajaran Biologi untuk Mengetahui Hasil Belajar Siswa pada Pokok Bahasan Ekosistem Kelas Vii Di Smpn 1 Talun. Jurnal Scientiae Educatia Volume 2 Edisi 1.

Martiyono. 2012. Perencanaan Pembelajaran. Yogyakarta: Aswaja Pressindo.

Misnah. 2014. Peningkatan Keterampilan Proses Sains dan Hasil Belajar IPA Melalui Penerapan Metode Direct Instruction Pada Siswa Kelas VII SMPN 1 Praya Timur Tahun Pelajaran 2014/2015. FPMIPA: IKIP Mataram.

Muhammad. 2014. Penerapan Keterampilan Proses Sains Pada Praktikum Jaringan Tumbuhan di Kelas XI IPA SMA Negeri. Artikel penelitian Universitas Tanjungpura. Pontianak.

Mustimah. 2013. Penerapan Pendekatan Keterampilan Proses untuk Meningkatkan Hasil Belajar Sains pada Siswa Kelas V SDN No. 2 Sikara Kecamatan Sindue Tobata. Jurnal Kreatif Tadulako Online Vol. 4 No. 8. ISSN 2354-614X.

Nurhayati. 2014. Peningkatan Hasil Belajar Siswa pada Pembelajaran Matematika dengan Menggunakan Pendekatan Matematika Realistik di Kelas II. Artikel Penelitian Universitas Tanjungpura. Pontianak.

Rohman. 2012. Manajemen pendidikan. Jakarta: PT. Prestasi Pustakaraya.

Rosdiana. 2013. Meningkatkan Hasil Belajar Sejarah Melalui Model Pembelajaran EPA (Eksplorasi Pengenalan dan Aplikasi Konsep) Pada Siswa Kelas VIII SMP Negeri 33 Makassar. Skripsi Fakultas Ilmu Sosial Universitas Negeri Makassar. 
Samsuri, T. (2016). Melatihkan Keterampilan Proses Sains Mahasiswa Biologi Melalui Pengembangan Perangkat Pembelajaran Guided Inquiry Pada Pokok Bahasan Klasifikasi Tumbuhan. Bioscientist: Jurnal Ilmiah Biologi, 4(2), 109-113.

Sugiyono. 2014. Statistik Untuk Penelitian. Bandung: CV Alfabeta.

Yuliati Y. 2016. Peningkatan Keterampilan Proses Sains Siswa Sekolah Dasar Melalui Model Pembelajaran Berbasis Masalah. Jurnal Cakrawala Pendas Vol. 2 No. 2 Edisi Juli 2016 ISSN: 2442-7470.

Zainifuza, 2013. Penerapan Model Pembelajaran Epa Untuk Meningkatkan Hasil Belajar Fisika Pokok Bahasan Listrik Dinamis Siswa SMA Negeri 1 Darul Imarah Aceh Besar. Skipsi Fakultas Keguruan dan Ilmu Pendidikan : Universitas Syiah Kuala Darussalam, Banda Aceh. 